\title{
Tourism and sustainable local development in the city of Cabo San Lucas, Mexico 1990-2015
}

\author{
A. Montaño ${ }^{1}$, A. Ivanova $^{1}$, G. Martinez ${ }^{2}$ \& J. Pérez ${ }^{1}$ \\ ${ }^{1}$ Universidad Autonoma de Baja California Sur, México \\ ${ }^{2}$ Universidad Autonoma de Baja California, México
}

\begin{abstract}
Since the early eighties, tourism has become the dominant axis of economic development in the city of Cabo San Lucas. The aim of this paper is to develop an analytical framework to assess the impact of tourism on the local sustainable development of Cabo San Lucas. The methodology applied is analyticaldescriptive, based on economic, social, demographic, and urban infrastructure variables. The temporary evaluation corresponds to the period 1990-2015. The quantitative analysis is complemented by qualitative information obtained from focus groups (group approach) to identify the valuation of local tourism performance by main stake-holders in the area.

The results allow to identify a number of imbalances and deficits currently affecting the city; for example, the accelerated process of immigration, coupled with an urban sprawl, promotes important lags in urban and social infrastructure. At the same time, the lack of a diversified productive base, capable of providing alternative employment and income, is generating excessive pressure on natural resources for tourism, which alienates this city from a model for sustainable tourism development.
\end{abstract}

\section{Introduction}

Tourism in Mexico represents an important source of foreign currency inflow, investment and employment, that's why this sector is of great economic impact in many regions of the country. Although the tourism is contributing to economic growth, and infrastructure generation in the receptor localities, it is not always a tool for the social development because of its negative impact on social, cultural 
and environmental components of adjacent urban areas. It is particularly noticeable for sun and beach touristic locations, where a remarkable population growth and strong immigration processes can be observed due to job opportunities and economic dynamism. Such situation is presented in many destinations and confirmed by numerous case studies [1].

From a regional perspective, in sun and beach destinations the main attraction is the coastline. That's why intensive land use is performed and the most of the urban-tourism investments are concentrated on the coast, since it is the most valuable territory of tourist cities [2]. At the same time the rest of urban areas presents a lack of territorial planning and becomes anarchic urban sprawl [3]. The problem aforementioned is the subject of this document, contextualized in the context of coastal towns, that are main receiving and support point for tourism activities, and multipliers for the local economy development [4], and where the jobs are concentrated in the service sector. In such cities the social and urban settings are centered in marketing of natural resources (beaches, sea, climate, and vegetation), exploitation of competitive advantages (as its geographical location) and the development of urban infrastructure and specialized services supporting tourism sector.

Therefore, as stated by Bojórquez Luque [5], these kinds of cities are urban spaces created or transformed by tourism, and conducive to the creation of residential tourist poles, territorial concentration and rapid growth of real estate sector (mostly unregulated). It is noteworthy that in cities with sun and beach tourism, urban development model adopts a dual or differentiated growth; on the one hand, the beach zone modified by the construction of large hotel chains, timeshare units, condominiums and exclusive residential complexes; on the other, marginalized areas for the majority of local population, historic center exceeded by the growth of the city, mostly informal commercial activity and a notorious urban anarchy, which leads to social and urban fragmentation.

In this perspective, the paper is developing an analytical framework to assess the impact of tourism and the implications of its growth on the sustainability of local development. The analysis is based on the case study of the city Cabo San Lucas, Baja California Sur, one of the main sun and beach tourist destinations in Mexico. The document integrates four sections; the first introduces the main features and concepts that allow to define a tourist city of sun and beach; immediately, the main methodological elements applied for this research are presented. The third part shows the results, starting with an analysis of the context of urban development of the city, and complementing this by a series of demographic, economic and urban development indicators. The documentary research is based, fundamentally, on the assessment and main strategies outlined by Urban Development Plan of San Jose del Cabo and Cabo San Lucas 2040 (PDU 2020) and Municipal Development Plan 2015-2018 of Los Cabos. Finally, the study is complemented by a qualitative research technique focus group. 


\section{Methodology aspects}

The document is based on concepts and general characteristics that define the processes of urbanization in tourist areas, whose product is called "tourist cities", applied in this case to the city of Cabo San Lucas. As previously stated the research is guided by two main documents: the Urban Development Plan of San Jose del Cabo and Cabo San Lucas 2040, and the Municipal Development Plan 2015-2018 of Los Cabos and statistical information from official sources such as National Institute of Statistic and Geography (INEGI) and National Population Council (CONAPO). On these documents are based the applied economic, social and demographic indicators; complemented by analysis of some variables of urban development.

The methodology used is mixed; initially the research was performed in analytical and descriptive way (consulting documentary sources), in order to contextualize the area under study. Subsequently, qualitative research was conducted by applying the technique "focus group", which is defined as "a discussion group guided by a set of questions carefully designed with a particular purpose" [6]. The objective of focus group was to assess the perception of experts on tourism and urban development of the city, including the problems above identified, as well as their proposals for improvement of the current urban situation. They were carried out three focus group exercises with participation of representative professional associations (Association of Architects, Engineers Association, section Los Cabos), local authorities (Department for Planning of Urban Development and Ecology and the Department of Economic Development and Tourism of Los Cabos municipality), organizations representing local business (Council of Business Coordinating and Real Estate Developers Association of Los Cabos), and academic institutions.

\section{Results}

\subsection{Integrally Planned Center (CIP) Los Cabos}

In 1976 Integrally Planned Center (CIP) of Los Cabos was created, being the third CIP created by National Fund for Tourism Development (FONATUR) in Mexico. Los Cabos is a tourist development which includes the cities of San Jose del Cabo and Cabo San Lucas, connected through a tourist corridor of $33 \mathrm{kms}$ (see figure 1). The main competitive advantage of this location at the southern end of the Baja California peninsula was to offer exclusive resorts, close to the west coast of the United States and Canada. The master plan of this CIP currently consists in a polygon of 915.78 ha., of which $6.32 \%$ are of urban areas, $76.96 \%$ tourist areas, and $16.72 \%$ conservation areas [7].

There are two important issues to consider in the spatial articulation of Los Cabos: the virtual isolation of their populations from the rest of the country; and the reason of the strong positioning of the location in the segment of medium-high, and high income tourists from California, Arizona, Nevada, Texas, New Mexico, Washington, Colorado and Canada. 
The growing economic importance of Los Cabos fostered the occupation of the coastal zone by foreign citizens and transnational corporations. These bought large areas in the tourist corridor between Cabo San Lucas and San Jose del Cabo, where luxury real estate developments have been built mainly for second homes or parttime occupation. The amount of retired North American citizens has been growing constantly, taking advantage of the good tourist infrastructure and geographic proximity to the United States [8].

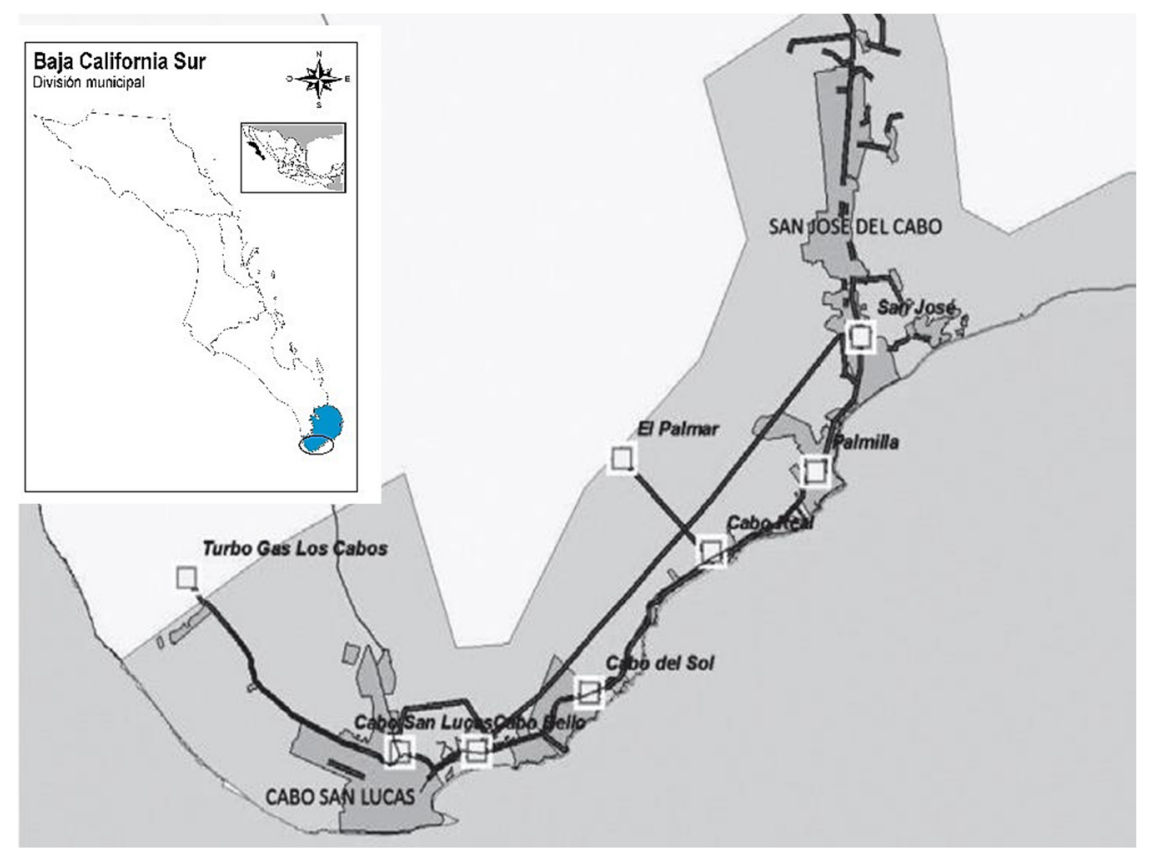

Figure 1: Cabo San Lucas and San Jose del Cabo: geographic location [10].

\subsection{Background and development of the City of Cabo San Lucas, Baja California Sur}

Within the National Urban System, the municipality of Los Cabos consists of two population centers: Cabo San Lucas and San Jose del Cabo, both located in the category of medium-sized cities with a population of 120.101 inhabitants and 160,585 inhabitants, respectively [9]. As a subunit of public administration, the city of Cabo San Lucas is delegation of the municipality of Los Cabos; geographically it is located at the southern tip of Baja California Sur in northwestern Mexico. The Gulf of California and the Pacific Ocean meet on its coasts (see Figure 1). This city can be reached by road from the city of La Paz (state capital) or by air, via Los Cabos International Airport. The town of Cabo San Lucas cannot be conceived without the existence of the neighboring city San Jose del Cabo. The two cities are connected by a highway parallel to the tourist 
corridor of Los Cabos, so between these locations there is a constant flow of human and material resources.

The name of Cabo San Lucas is attributed to one of its founders named Thomas Ritchie in 1828. Historically, the town had few inhabitants; in fact, in 1950, the population was only 548 inhabitants, most fishermen and cannery workers of the tuna factory Marine Products Company S.A. The initiative to develop the area came from a small group of businessmen, William Parr, Abelardo Rodriguez, Luis Coppola and Luis Bulnes, who since the late 1940s and early 1950s began to buy land and small ranches in the area, and build hotels and resorts. The first hotel was Hotel Palmilla, lacated in the tourist corridor, and founded in 1956, a very exclusive resort popular among Hollywood celebrities, with golf course and private landing track. Later in 1959, opened the hotel Chileno Bay, the first hotel in Cabo San Lucas (which takes its name from pirates of that nationality that devastated the area in the eighteenth century). Among the first hotels in the area count hotel Hacienda in 1963, Hotel Sea of Cortez in 1972, and hotel Solmar in 1974.

During the eighties, the city of Cabo San Lucas began to grow, spurred by large investments in tourism, trade, real estate, high value construction, prompting a notorious phenomenon of internal migration. The municipality of Los Cabos and specifically Cabo San Lucas became a pole of attraction for people from other municipalities in the state of Baja California Sur, and mainly for immigration from other Mexican states. In these circumstances the town center was consolidated near to the port area and its shopping center. Thus, the expansion of urban area doubled by 1993, being urbanized the surrounding zones (some of which were common lands as Ejidal colonies and Arenal), as well as the Workers and March 4. The neighborhood Lomas del Sol was also urbanized as a suburb colony. At the same time, settlements for high income foreign residents were established, e.g. El Pedregal developed near the marina of Cabo San Lucas [5]. The largest territorial expansion of the city took place during 1993-2004, when many new neighborhoods emerged, e.g. Los Cangrejos, Miramar, Jacarandas, La Jolla, Arcos del Sol, Lagunitas, Mesa Colorada, El Caribe and other exclusive developments located in the tourist corridor.

\subsection{Urban structure and mobility}

For purposes of this paper and according to definitions of the Urban Development Plan Los Cabos 2040, urban structure is understood as "set of elements that constitute the base for the functioning of the city: physical elements, build and natural, and socioeconomic factors that influence the growth and evolution of the city" [10]. In the opinion of the Director of Urban Development of San Jose del Cabo and Cabo Plan San Lucas 2040 (PDU 2040) Los Cabos can by analyzed as the same population center, that is located at the southern end of the municipality, and integrates the cities of San Jose del Cabo, Cabo San Lucas, the Tourist Corridor and adjoining localities, with an area of 54,551.49 hectares. The same document states that the growth of urban sprawl in Cabo San Lucas, went from 146 hectares in 1976 to more than 2,000 hectares in 2012. These data illustrate the degree and accelerated pace of urban growth experienced by the city. 
The center of Cabo San Lucas is the main node of shops and services, and the main tourist activity. In this place are located the Marina, the Cultural Pavilion and the famous Medano Beach, areas which concentrate the majority of the commerce, entertainment and tourism services. Here can be found also many important hotels located along the Lazaro Cardenas Avenue. This zone is visited constantly by tourists that come in search of recreation activities, thus creating an emerging urban sub-center.

In contrast, the urban mobility in the rest of the city is not consolidated and shows a lack of connectivity and efficiency causing problems for traffic flow. Cabo San Lucas has a total of $370,454.27$ meter roads, but only $38.30 \%$ of them are paved. The difficulties are multiplied by the big number of cars. Official statistics register 1 vehicle per 3.5 persons, however there is a lot of unregistered vehicles owned by local or foreign residents. In addition, the city does not have sufficient spaces for parking, and presents shortage of quality alternatives for pedestrians and people with disabilities.

The perception of experts on urban structure that participated in the "focus group" indicates that - due to the high rates of floating and migrant population one of the great challenges, is the lack of identity in a high percentage of the population [10] of the urban area of Cabo San Lucas. These people do not perceive the city as their home and therefore, do not respect public spaces and do not care for the environmental protection. A further implication of this lack of identity is the increasing insecurity and the lack of interest to take part in public policies. In this sense, the public space constitutes one of the means to improve the quality of life, strengthen spirit of community and define the identity, because in those areas the citizens feel as inhabitants of the same place. Currently, in Cabo San Lucas there are only 18.7 hectares of green areas in urban spaces. The index is $2.17 \mathrm{~m}^{2}$ of green area per inhabitant, in contrast with the recommendation of the World Health Organization of 10 to $12 \mathrm{~m}^{2}$, and presenting a deficit of about 9 square meters. That's why one of the priorities of urban policies is the rehabilitation of existing public spaces and the creation of more and better areas for inclusive public entertainment for locals and tourists. In the last years, the deficit of public open spaces for recreation (parks, squares, etc.) has been increasing. It does not exist any normativity for tourism-real estate developers to allocate specific green areas within the urban non-tourist area of the city. This situation has caused an imbalance between urban and tourist area in the city, because in the coastal zone there are more recreation areas (and beaches) but exclusively for tourists.

The focus group it concluded unanimously that there are fundamental problems in infrastructure for drinking water, drainage and solid waste disposal, not having enough coverage or the technical characteristics for proper operation and/or management. A major issue is drinking water; the experts stress the limited coverage and permanent service provision. For example, they mention that $64 \%$ of users receive water service intermittently (usually every other day), so the shortage of water is identified as one of the main urban social problems in Cabo San Lucas. In sanitation, there is a significant lag in coverage of drainage networks, in fact sewage coverage in 2012 reached only $59 \%$ of households. In terms of solid waste, the city generated $1.13 \mathrm{kgs}$./hab./day, being that a high indicator. But the 
main problem is that the city does not have a landfill that complies with current standards, to which must be added the limited lifetime of the current "garbage dumps", making this one of the priority issues for local authority and society. Some tourism enterprises could also support the activities in these areas.

It is important to note that, in the case of Cabo San Lucas, implementation of the model called "pole of tourism development" through a CIP, generated morphological and functional changes that necessarily involved structural adjustments in urban matters. The investment boom in the construction of hotels and real estate of high value, increased property speculation due to the high demand for land and buildings [11], thus it was promoting intensive land use in coastal space, allowing private ownership of the beach for large multinational hotel chains and luxury enclaves' formation. The housing market began operating in coordination with the hotel market (which was the initial start of tourism development in Cabo San Lucas) through the supply of timeshare units and second residences for foreign tourists and retirees mainly from the United States and Canada. The link between tourism and real estate market often has negative consequences in tourist areas [12], because landscapes are altered (from the aesthetic point of view). Conflicts are generated between the economic and social actors, and have a strong impact on local ecosystems. It is noteworthy that in the absence of a regulatory instrument or a plan referred to urban tourism planning (to define rules of land use and property), tourism development of the city was handed over to private interests until 2011, when the Urban Development Plan of San Jose del Cabo and Cabo San Lucas with projection 2040 started.

\subsection{Socioeconomic and environmental issues}

The demographic dynamism observed in Cabo San Lucas coincides with indicated by Vera and Baños [4: 335], who state: "in regions that in recent decades registered significant tourist flows, a strong correlation between tourism development and demography is verified". The areas of tourism development become attractive for investors and for economically active population (EAP) in search of employment opportunities and higher incomes. In the case of the city of Cabo San Lucas, in the period between 1990 and 2015, the population increased by $900 \%$ from 16,059 inhabitants to 160,585 , representing an average annual growth rate of $15 \%$, which turns out to be very high and well above the national average (see Table 1).

The highest growth rate occurs between 2000 and 2005, from 48,032 to 87,776 inhabitants which represents an average annual rate of $16.5 \%$, much higher than the national average. Note that in this period the consolidation and maturity of the CIP Los Cabos is reached and as mentioned in previous research Montaño et al. [11], subsequent indicators recorded a lower growth rate, particularly after the subprime crisis of 2008. This affected both the tourism flow, and the construction, but mainly the real estate sector offering of timeshare units and second homes for foreign tourists. While it is true that the projections of CONAPO 2015 indicate a decrease in population growth in Cabo San Lucas between 2010 and 2015, it is no less true that the impact and damage caused by Hurricane "Odile" in September 2014, pleading for a strong investment growth in the construction sector (not only 
reconstruction, but also the beginning of new and large hotels and real estate projects), has led again to a noticeable flow of immigration to the city.

Table 1: $\quad$ Population by location in the Municipality Los Cabos [9].

\begin{tabular}{|c|c|c|c|c|c|c|c|}
\hline \multirow{2}{*}{ City } & \multicolumn{4}{|c|}{ Population } & \multicolumn{3}{c|}{ Growth rate } \\
\cline { 2 - 8 } & 1990 & 2000 & 2010 & 2015 & $\begin{array}{c}1990- \\
2000\end{array}$ & $\begin{array}{c}2000- \\
2010\end{array}$ & $\begin{array}{c}2010- \\
2015\end{array}$ \\
\hline $\begin{array}{c}\text { San Jose del } \\
\text { Cabo }\end{array}$ & 18,405 & 40,647 & 91,386 & 116,673 & $120.8 \%$ & $124.8 \%$ & $27.7 \%$ \\
\hline $\begin{array}{c}\text { Cabo San } \\
\text { Lucas }\end{array}$ & 16,059 & 48,032 & 128,057 & 160,585 & $199.0 \%$ & $166.6 \%$ & $25.4 \%$ \\
\hline Rural area & 3,276 & 4,327 & 4,750 & n.d & $32.1 \%$ & $9.8 \%$ & n.d \\
\hline
\end{tabular}

Before the rapid growth of tourism, the economic structure of Cabo San Lucas, was based on coastal fisheries, livestock and sport fishing. After the boom of tourism and real estate investments since the nineties, tourism occupied the place of traditional activities. The city is developed based on this dominant economic activity, fostering a process of tourist development, but neglecting the needs of infrastructure and urban development for local population. Referring to the environment: "the unplanned urban sprawl causes high impact on the environment due to the high land use for urbanization, also it causes impacts on natural protected areas and aquifer recharge zones, pollution of seas and beaches, among others negative effects" [10: 149].

Cabo San Lucas is an example of the principle that in the economy of a tourist city, consumption prevails over productive activities [4]. That's because tourists choose these cities as places to carry out their wishes, "turning them into temporary agglomerations of services and leisure items offered to foreign customers" [13]. Because of that most jobs are concentrated in the services sector, so like other tourist cities of similar characteristics, $79.3 \%$ of the economically active population of Los Cabos [14], is located in this sector. This fact is reflecting a high dependence on tourism (for economic development) and lack of diversity in productive activities.

Moreover, $67.7 \%$ of the economic units registered by INEGI in Cabo San Lucas in 2015 are performing in trade, tourism, real estate, transportation and other services directly related to tourism. This reality coincides with the vast majority of tourist cities, where urban areas are essentially tertiary centers, specialized in tourist functions, entertainment, leisure and real estate. Even though the sector of real estate and rental represent only $3.36 \%$ of economic units registered by INEGI in Cabo San Lucas, is evident its strength and impact on the local economy, since its supply not only includes buildings for tourism, but also the sale of timeshare units, which have been a major stimulus to development and multiplier for other economic sectors. The economic contribution of the real estate firms is significant, but the supply is concentrated in a few companies. 

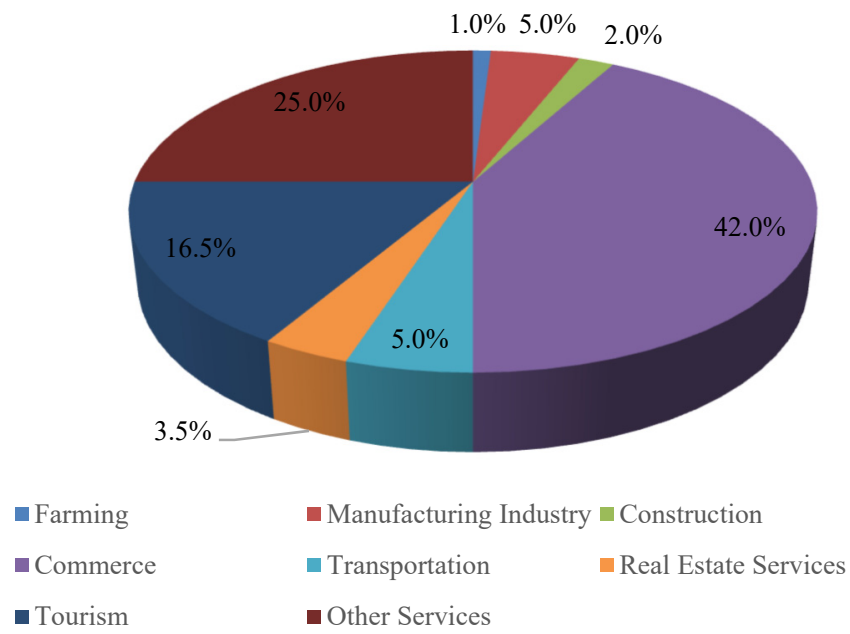

Figure 2: Distribution of employment in the City of Cabo San Lucas [14].

\section{Conclusions}

Considering the urban, tourist and economic indicators, in Cabo San Lucas tourism performs the role of main economic engine. However, at the same time at as in other integrally planned tourist destinations in Mexico - is a reality that tourism activity has failed to link with the primary and secondary sectors of the local economy and did not take advantage of its momentum and growth to foster the development of other sectors (such as fishing, farming or industry). These could become suppliers to the predominant tourism sector and thus encourage more balanced growth at the local level. Finally, it is necessary to refer that while tourism has been the economic engine in the city, it has also failed to promote sustainable tourism development, but rather has established a model of real estate tourism, uncommitted with the environment and with the societal needs. Planning and management of urban and economic development has been limited to meet the short term needs without a comprehensive approach. Therefore, it is important that the policies of urban development of the city, consider the strategies and measures of priority action on infrastructure, public space, green areas and environmental protection. These measures are already included in the Urban Development Plan 2040, and their implementation will create a more accessible, efficient and sustainable city.

\section{References}

[1] S. Lionetti and O. Gonzalez., On the relationship between tourism and growth in Latin America, Tourism \& Hospitality Research, vol. 12, no. 1, pp. 15-24, 2012. 
[2] P. Mullins., The evolution of Australian tourism urbanization, in Cities and visitors, L. Hoffman, S. Fainstein, and D. Judd, Eds. Londres, Inglaterra: Blackwell Publishing, pp. 126-144, 2003.

[3] N. Körössky, I. Dias e Cordero, and J. M. Henriques Simöes., La génesis de las ciudades turísticas. Un análisis del proceso de urbanización turística de Portinao (Portugal), Estudios y Perspectivas en Turismo, vol. 23, pp. 176189, 2014.

[4] F. Vera and C. Baños, Renovación y reestructuración de los destinos turísticos consolidados del litorial: las prácticas recreativas en la evolución del espacio turístico, Boletín la Asociacion de Geográfos Españoles, vol. 53, pp. 329-353, 2010.

[5] J. Bojórquez Luque., Evolución y planeación urbana de la ciudad turística de Cabo San Lucas, Baja California Sur (México), Pasos, Revista de Turismo y Patrimonio Cultural, vol. 12, no. 2, pp. 341-356, 2014.

[6] R. Hérnandez, C. Fernández, and P. Baptista, Metodología de la investigación. México, D. F.: Mc Graw Hill, 2006.

[7] FONATUR., Proyectos y desarrollos, Proyectos y desarrollos, 2016. [Online]. Available: WWW.FONATUR.gob.mx/es/index.asp.

[8] D. Hiernaux., Repensar la ciudad: la dimensión ontológica de lo urbano, LiminarR Estudios Sociales y Humanisticos, vol. IV, pp. 7-17, 2006.

[9] CONAPO., Proyecciones de población a nivel localidad 2010-2030, Ciudad de México, México, 2016.

[10] IMPLAN., Segunda Actualización del Plan Director de Desarrollo Urbano San José del Cabo y Cabo San Lucas, San José del Cabo, México, 2013.

[11] A. Montaño, J. C. Pérez, and V. de la O., Reposicionamiento para destinos turísticos consolidados: el caso de Los Cabos, México, Cuadernos de Turismo., no. 33, pp. 271-295, 2014.

[12] E. Navarro, D. Thiel, and Y. Romero., El impacto de los modelos turísticos dominantes en destinos litorales, estudios de casos en Andalucía, el Caribe y Centroamerica (Capitulo 6), in Turismo responsable, sostenibilidad y desarrollo local, M. Rivera and L. Rodriguez, Eds. Córdoba: Catedra Intercultural, Universidad de Córdoba, España, pp. 119-144, 2012.

[13] G. Mascarenhas., Cenários contemporaneos da urbanizacao turistica, Cuaderno Virtual de Turismo, vol. 4, no. 4, pp. 1-11, 2004.

[14] INEGI., Anuario estadístico y geográfico de Baja California Sur. Aguascalientes, México: Instituto Nacional de Estadística y Geografía, 2015. 